\title{
Enhancing Peer Interaction in Early Childhood Special Education: Chains of Children's Initiatives, Adults' Responses and Their Consequences in Play
}

\author{
Marja Syrjämäki ${ }^{1}$ [D Päivi Pihlaja ${ }^{2}$ Nina K. Sajaniemi ${ }^{3,4}$
}

Published online: 28 May 2019

(c) The Author(s) 2019

\begin{abstract}
This article focuses on the initiatives taken by children and the responses given by professional adults with regard to the pedagogy of enhancing peer interaction among diverse learners. The study took place in four integrated special groups of public early childhood education. In groups of this kind, typically developing children and those with special educational needs (SEN) spent time together on a daily basis. We analysed 12 videotaped play sessions with 33 (3- to 6-year-old) children and 10 adults to examine the children's initiatives, the adults' responses, and the consequences that ensued. The study revealed verbal and nonverbal initiatives followed by a variety of responses scaffolding the children's interaction and participation. However, the nonverbal or faint initiatives, especially those taken by the children with SEN, were at risk of being unnoticed or ignored. These findings call for professional reflection on pedagogical sensitivity in recognizing and responding to the initiatives of children.
\end{abstract}

Keywords Initiatives $\cdot$ Responses $\cdot$ Peer interaction $\cdot$ Special needs $\cdot$ Social scaffolding $\cdot$ Pedagogical sensitivity

Electronic supplementary material The online version of this article (https://doi.org/10.1007/s10643-019-00952-6) contains supplementary material, which is available to authorized users.

\section{Marja Syrjämäki}

marja.syrjamaki@helsinki.fi

Päivi Pihlaja

paivi.pihlaja@utu.fi

Nina K. Sajaniemi

nina.sajaniemi@helsinki.fi

1 Faculty of Educational Sciences, University of Helsinki, Siltavuorenpenger 5, PO Box 9, 00014 Helsinki, Finland

2 Department of Education, University of Turku, Assistentinkatu 5, 20014 Turku, Finland

3 Faculty of Educational Sciences, University of Helsinki, Siltavuorenpenger 10, PO Box 8, 00014 Helsinki, Finland

4 Philosophical Faculty, School of Applied Educational Sciences and Teacher Education, University of Eastern Finland, P.O. Box 111, 80101 Joensuu, Finland

\section{Introduction}

Peer interactions in early childhood education (ECE) groups, as well in mainstream and special education, can be compromised because of individual needs and characteristics of the children involved. According to Kronqvist (2004), initiatives, responses, fostering new initiatives, and shared meanings form a continuum of collaboration among children. In this paper we were interested in children's initiatives and the importance of professional adults' reactions and responses to those initiatives with regard to enhancing peer interaction. The study was conducted in four integrated special groups in Finland. ${ }^{1}$ Although carried out in the context of early childhood special education (ECSE), the study is situated within the framework of inclusive early childhood education in which the goal is to increase social interactions among diverse learners (see Terpstra and Tamura 2008). The study is conducted

\footnotetext{
$\overline{1}$ In Finland, about $85 \%$ of kindergarten-aged children with SEN attend daycare in inclusive ECE groups. The rest are placed in special education groups in public kindergartens. Most of those $(85 \%)$ are integrated special groups, which are also inclusive in that most of the children are developing typically (usually seven are without SEN and five have SEN). Moreover, there is also a minority of segregated special groups in which all children have special support (Pihlaja 2009).
} 
in an ECE context in which typically developing children and children with SEN play and learn together on a daily basis.

\section{Peer Interaction and Play in Early Childhood Education}

In our article, peer interaction and play are considered fundamental aspects of full participation. Free-flowing, childinitiated play is a typical context for peer interaction, and shared activity and imagination in play promote cognitive development as well as social development. By playing with peers, children share their routines and their values and experiences (Corsaro 2005; Bodrova and Leong 2007). At the same time, in horizontal relationships children learn new functions in ways that are not possible in the vertical dyadic interaction between an adult and a child (Schaffer 2006; de Groot Kim 2005; Kemp et al. 2013). The role of play is often highlighted as a context for learning, particularly in the case of children with SEN (Brodin 2005; Kilburn and Mills 2014; Barton 2015). Still, interaction with others and belonging to a group is an innate human need as well as being the core of inclusion (see Ryan and Deci 2000; Koster et al. 2009). The concept of social participation refers especially to the social aspect of inclusion. The social participation of diverse children contains positive social relationships as well as the perception of acceptance by peers. The consequences of unsatisfying peer relations can be social isolation and loneliness, social rejection, or even bullying, along with negative self-perception of social competence (Koster et al. 2009).

As Kronqvist (2004) has stated, children's initiatives and responses are the basic elements of social accession and interaction among children. In her study the most common initiatives among young children were verbal calls for cooperation in shared play. Gestures such as lingering looks or following ongoing activities were summonses to interaction. Initiatives were answered in various ways: functionally, with a gesture, question, or comment or by ignoring the initiative. Many initiatives remained unanswered, especially among the youngest children. As a consequence, a child might have repeated an initiative, but the unheeded act could also lead to ending collaboration or to solitary play (Kronqvist 2004). Several studies have shown that nonverbal initiatives, such as making gestures, looking at or moving towards another child, or even negative contacts are usual with the youngest children. As well, the initiatives or social abilities of children with SEN might be fewer or more limited than those of their typically developing peers (Smith et al. 2017; Girolametto and Weitzman 2002; Paparella and Kasari 2004). A child's attempts to join in play might also be misunderstood by peers, due to his/her inadequate peer interaction skills or situationally inappropriate behaviour (Laaksonen 2014; Meyer and Ostrosky 2016).

\section{The Role of Professionals in Enhancing Peer Interaction}

As pointed out, interaction in peer groups and play activities is not straightforward. When the participation in the activity is too demanding for the child, he/she needs the scaffolding provided by an adult or another child (Bodrova and Leong 2007). Suhonen (2009) demonstrated that young children with SEN observed other children and their activities but had very little spontaneous interactions because of difficulty in regulating their own functions and sharing activities. The committed guidance of early childhood education professionals is essential for children's joining, participating and interacting in peer groups (Suhonen 2009; see also Suhonen et al. 2015; Meyer and Ostrosky 2016; Acar et al. 2017).

Participating in play is linked to communication and language (e.g. Singer and de Haan 2007; Juutinen 2015). However, Kultti (2015) has shown in her study that participation can even be the silent involvement of observing play activities, highlighting the teacher's crucial part in supporting the child's trajectory towards active participation and playing. The adult should be sensitive in recognizing a child's initiative in terms of opportunities for interacting and modelling the interplay. The role of a professional might be to scaffold for a child, as well as to prompt initiatives in response to those of another child or children (Brown et al. 2001; Suhonen 2009; Movahedazarhouligh 2018). The adult's response to the initiative can be directed at an individual child, (e.g., to support communication with augmentative or alternative communication systems) but the response can also be focused on the environment in such a way as to turn the child's adult-focused initiative into peer interaction (Syrjämäki et al. 2017). Adults as well as children use the repertoire of verbal and nonverbal communication, evident in their responses to children's initiatives (Girolametto and Weitzman 2002; Bae 2012). Nonverbal codes, such as facial expressions and gestures as well as postures and movements, are presented in addition to vocal and verbal input. Nonverbal communication, even more powerful than verbal, plays a crucial role. A nonverbal response that conflicts with a verbal message offers a crucial cue for interpreting the sender's actual meaning (Burgeon et al. 2013).

Although previous studies have discussed the matter of children's initiatives (e.g. Girolametto and Weitzman 2002; Paparella and Kasari 2004; Kronqvist 2004; Singer and de Haan 2007; Smith et al. 2017; Viljamaa et al. 2017) and adult roles and responses (e.g. Kemp et al. 2013; Barton 2015; Movahedazarhouligh 2018; Anderson et al. 2017), less attention has been paid to the initiative/ response patterns with relation to peer interaction. We 
have shown in our earlier study (Syrjämäki et al. 2018), that adults respond to children's initiatives in various ways. We found that, notwithstanding the successful pedagogical practices aimed at interactions in play, professionals missed some of the initiatives, in particular those taken by children identified as having special needs. In this article we continued with the research material gathered in the previous phase of our study and strove for more detailed information of the kinds of social initiatives made by children during guided play activities. Although we observed every child in play, we focused slightly on the children with SEN because of the probabilities of compromised peer relations revealed in earlier studies (e.g. Laaksonen 2014; Repo 2015; Juutinen 2015; Meyer and Ostrosky 2016). We were also interested in how the professionals reacted and responded to these initiatives, as well as how the responses related to peer interaction, and what kinds of consequences ensued in integrated special groups. We posed the following questions:

1. What kinds of social initiatives did children make in guided play activities?

2. How did the ECSE professionals respond to the children's initiatives?

3. What consequences followed from the chains of initiatives and responses?

\section{Method}

The study draws on the tradition of visual ethnography (see Pink 2007), seen here as a way of experiencing and interpreting pedagogical culture, a field which has emerged in certain integrated special groups in Finnish kindergartens. We used an ethnographic method of data acquisition, meaning that the video material was used not only for creating data about what is happening in the kindergarten group, but also for recognizing the significance of the process of producing the knowledge and the context in which the knowledge has been generated. Knowledge created in the ethnographic research process was based on the researcher's own experience (Pink 2007). Moreover, using video material made it possible to examine the multimodal character of interaction-not only the language and verbal aspects, but also the nonverbal features of communication (see Flewitt 2006). In our study visual and written data were linked. We used video recordings as our main source material. The field notes on our observations and short discussions with the participating professional team members provided material to support our interpretation.

\section{Participants and Research Material}

Four integrated special groups participated in this study. The groups representing higher and lower levels of quality in enhancing peer interaction were selected based on a quality assessment conducted with the Learning Environment Assessment (Strain and Joseph 2004) during the earlier phase of our studies (see Syrjämäki et al. 2017). In those groups 23 of 50 children ages 3 to $5 \mathrm{had}$ special needs. According to the teachers and the evaluation of the clinical neuropsychologist, the main areas of children's SEN were difficulties with self-regulation, language and/or interaction (see Suhonen et al. 2015). Each of the professional teams consisted of four members: two ECSE teachers, a nursery nurse and a teaching assistant (Table 1).

In total, five group meetings and 18 play sessions were video recorded for three visits to each of the participating kindergarten groups. Of the original material filmed during the play sessions, which consisted of $17 \mathrm{~h}$ and $21 \mathrm{~min}$, we conducted a closer analysis of $8 \mathrm{~h}$ and $48 \mathrm{~min}$. The material chosen for analysis fulfilled three conditions: the children were playing (imitation or functional/fictional/socio-dramatic play; see Online Appendix 1), a child or children with SEN were involved, and an adult took part or was present in the play. A total of 14 play sessions met these requirements: five sessions of Group A and three sessions of Groups B, $\mathrm{C}$, and D. On the grounds of the preliminary analysis of the material, the last two play sessions of Group A did not offer any divergence or new information about the phenomenon in question. We defined our rich material as saturated (Fusch and Ness 2015), and the data from play sessions A4 and A5 were extrapolated from and defined based on the final analysis. Thus, the number of analysed play sessions was 12 , consisting of three sessions from each of four participating groups. Altogether, 10 ECSE professionals and 33 children, 15 of whom with SEN, took part in the analysed play activities (Online Appendix 1).

\section{Analysis}

We utilized the video recordings as a source for the inductive data analysis, guided by the defined theme, but without a strong theory or classification driving the analysis. From the entire video corpus, the fragments essential to our research questions were selected for deeper analysis (see Derry et al. 2010). For a start, the first author watched the 14 video-recorded play sessions that met the requirements for the analysis. This tentative examination provided the idea for conducting a deeper analysis of the material: of the initiatives observed there, those taken by children with SEN were selected as were initiatives taken by typically developing children in sessions in which their peers with SEN were in attendance or even actively 
Table 1 The participating kindergarten groups

\begin{tabular}{|c|c|c|c|c|}
\hline \multirow{2}{*}{$\begin{array}{l}\text { Professional team members (all females) } \\
\text { Position/schooling, if not qualified for the position }\end{array}$} & \multicolumn{4}{|l|}{ Children } \\
\hline & Age in years & $\begin{array}{l}\text { Additional needs/con- } \\
\text { sent }+ \text { on the video }\end{array}$ & $\begin{array}{l}\text { Typically developing/ } \\
\text { consent + on the video }\end{array}$ & $\begin{array}{l}\text { Codes of the } \\
\text { children on the } \\
\text { video }\end{array}$ \\
\hline \multicolumn{5}{|l|}{ Group A } \\
\hline $\mathrm{A} 1=\mathrm{ECSE}$ teacher & $4-6$ & $2 / 2$ girls & $3 / 3 / 2$ girls & G1-G5 \\
\hline $\mathrm{A} 2=\mathrm{ECSE}$ teacher & & $4 / 3$ boys & $3 / 3 / 3$ boys & B1-B5 \\
\hline$*$ Nursery nurse & & In total $6 / 5$ & In total $6 / 5$ & In total $12 / 10$ \\
\hline \multicolumn{5}{|l|}{ *Teaching assistant/no schooling } \\
\hline \multicolumn{5}{|l|}{ Group B } \\
\hline $\mathrm{A} 3=\mathrm{ECSE}$ teacher & $3-6$ & $0 / 0 / 0$ girls & $5 / 2 / 2$ girls & G6-G7 \\
\hline $\mathrm{A} 4=\mathrm{ECSE}$ teacher & & $5 / 3 / 3$ boys & $2 / 2 / 2$ boys & B6-B10 \\
\hline$*$ Nursery nurse & & In total $5 / 3$ & In total $7 / 4$ & In total $12 / 6$ \\
\hline *Teaching assistant/other schooling & & & & \\
\hline \multicolumn{5}{|l|}{ Group C } \\
\hline $\mathrm{A} 5=\mathrm{ECSE}$ teacher & $3-6$ & $0 / 0$ girls & 4/1 girls & G8 \\
\hline $\mathrm{A} 6=\mathrm{ECSE}$ teacher/nurse & & $6 / 4$ boys & $3 / 3$ boys & B11-B17 \\
\hline *Nurse/other & & In total $6 / 4$ & In total $7 / 4$ & In total $13 / 8$ \\
\hline \multicolumn{5}{|l|}{$\mathrm{A} 12=$ teaching assistant } \\
\hline \multicolumn{5}{|l|}{ Group D } \\
\hline $\mathrm{A} 13=\mathrm{ECSE}$ teacher & $3-6$ & $1 / 0$ girls & $5 / 3$ girls & G9-G11 \\
\hline $\mathrm{A} 14=\mathrm{ECSE}$ teacher & & $5 / 3$ boys & $2 / 2$ boys & B18-B22 \\
\hline A15 = nurse & & In total $6 / 3$ & In total $7 / 5$ & In total $13 / 8$ \\
\hline *Teaching assistant/no schooling & & & & \\
\hline$N=16$ & & $\mathrm{n}=23 / 15$ & $\mathrm{n}=28 / 18$ & $\mathrm{~N}=50 / 33$ \\
\hline
\end{tabular}

*Not on the video material

participating. Every fragment selected for analysis contained a child's initiative and an adult's response, as well as a consequence of the initiative-response continuum. As explained earlier, the data from play sessions A4 and A5 were left out of the analysis, and the total number of the sessions for the final analysis was 12 .

Based on a preliminary understanding of the selection, the first author then chose at random 20 fragments from 12 play sessions to analyse piecemeal in collaboration with the second author. The chosen fragments represented Groups A-D and different kinds of initiatives and responses. The children's initiatives and the responses given by the adults were identified and classified in preliminary main categories and subcategories. Fragments of the video material were shown to the third author, and the interpretation, which was consistent among the three authors, was discussed to find adequate concepts. The analysing frame was constructed by formulating the data-driven subcategories into each main category (see Schreier 2012) (Tables 2, 3). To quote Derry et al. (2010, p. 15), the analysis was "an iterative process that involves moving back and forth among the process of video selection; one's evolving interpretations and hypotheses, and a variety of intermediate representations for discovering, evaluating, and representing the video data to oneself and others."

The first author continued with a closer examination, discussing regularly with the other authors. The process began with the first three play sessions of Group A (sessions A1, A2, A3). The material was sifted and assigned a place in the frame, constructed in collaboration among the two first authors. Initiative-response sequences were identified; then the sequences were posed side-by-side to distinguish different initiative-response-consequence patterns. The same procedure was repeated with the material of Groups B, C and D. After each round of analysis, the coding frame was revised, with new subcategories added if needed. During the process, the transcription was used as essential data along with the videos, enabling additional coding and interpretation (see Derry et al. 2010).

\section{Trustworthiness}

The consistency of the process was examined by comparing, covering approximately $20 \%$ of the analysed video data, first encoded independently and then compared the interpretations by the first and the second author. The correlation 
Table 2 Children's initiatives in play

\begin{tabular}{|c|c|c|c|c|c|}
\hline Main category & $\mathrm{n}$ & Percent & Subcategory & Meaning & Example (play) \\
\hline \multirow[t]{4}{*}{ Nonverbal } & 30 & 10 & Physical & A movement (toward), handling a toy & $\begin{array}{l}\text { Turns around, takes a train and starts } \\
\text { to drive to the same direction than } \\
\text { another child }(\mathrm{C} 1)\end{array}$ \\
\hline & 21 & 7 & Gesture & $\begin{array}{l}\text { Directed glances/looks, eye contact, } \\
\text { clapping hands }\end{array}$ & $\begin{array}{l}\text { Comes to the teacher, points to a toy } \\
\text { (B3) }\end{array}$ \\
\hline & 21 & 7 & Non-directed nonverbal & $\begin{array}{l}\text { Throwing an object/toy, non-directed } \\
\text { play initiative }\end{array}$ & $\begin{array}{l}\text { Starts driving a toy-car (A1). nursing a } \\
\text { doll (A3) }\end{array}$ \\
\hline & 25 & 8.5 & Directed nonverbal & Directed play initiative & $\begin{array}{l}\text { Goes to the receptionist (A3) starts } \\
\text { treating the patient (A3) }\end{array}$ \\
\hline Functional-verbal & 26 & 9 & Functional-verbal & $\begin{array}{l}\text { Functional (play) initiative with short } \\
\text { verbal expression }\end{array}$ & $\begin{array}{l}\text { Drives a police car toward the } \\
\text { other children "UII-UIII-UII. The } \\
\text { car..." (D1) }\end{array}$ \\
\hline \multirow[t]{4}{*}{ Verbal } & 25 & 8.5 & Non-directed verbal & Comment, question & $\begin{array}{l}\text { "Police" (A1)." I'm the patient" (A3)." } \\
\text { Who is coming?" (A2) }\end{array}$ \\
\hline & 44 & 15 & Adult-directed verbal & Comment, question & $\begin{array}{l}\text { "I'm helping him" (A3.)" } \\
\text { "When is my turn?" (B1) }\end{array}$ \\
\hline & 103 & 35 & $\begin{array}{l}\text { Interactive (child- } \\
\text { directed) play-initi- } \\
\text { ative }\end{array}$ & $\begin{array}{l}\text { Aiming to interactive play, taken in } \\
\text { a role }\end{array}$ & $\begin{array}{l}\text { "You can set the food here" (B1) } \\
\text { " May I have some more?" (C3) }\end{array}$ \\
\hline & $\mathrm{N}=295$ & 100 & & & \\
\hline
\end{tabular}

between the two researchers concerning the compared material was $93 \%$. During the research process, the three researchers contributed to the internal reliability of the study by discussing the underlying theories regularly, as well as discussing the analyses, interpretations, especially when inconsistent, and conclusions. The results as well as the preceding analyses have been presented step by step, using examples and quotations as accurately as possible, to ensure the transparency of the study (see Seale 1999; Flick 2007).

In the next section, we present the findings of the research questions on children's initiatives, professionals' responses, and identified initiative-response-consequence chains with narrative and quantifying tables. In addition to describing the analysed qualitative data, we highlight some interesting findings with examples from the video material. After that, we summarise the main findings of our study.

\section{Findings}

\section{Initiatives and Responses}

Two main initiative categories (Table 2)-nonverbal and verbal-were identified during the preliminary analysis described above. In the deeper analysis of the material, those categories were supplemented with a further category: functional-verbal. The two first main categories of responses (Table 3) were also called nonverbal and verbal. Based on our data, we added two more categories: unnoticed and ignored.
A total of 295 initiatives and responses were identified from the analysed video material. Our analysis revealed three main categories of initiatives. Nonverbal contained non-directed/directed physical initiatives, non-directed/ directed gestures and non-directed/directed play initiatives. Functional-verbal initiatives were taken by children who were active in playing but might have had limited verbal abilities: the functional part was emphasized. Verbal were either non-directed or directed towards an adult or other child or children. If an initiative consisted of nonverbal and verbal parts that were in line with each other, it was categorized as verbal. As explained earlier, only the initiatives directed to or connected in some other way with the children with SEN were analysed. Of those, 197 initiatives were taken by children with SEN; 98 were taken by their typically developing peers. Among the initiatives taken by the former, 38\% were nonverbal, whereas the percentage of the latter was $22 \%$.

Of the responses given by the professionals to children's initiatives, $9 \%$ of nonverbal and verbal initiatives remained unnoticed and $5.4 \%$ were ignored by the ECSE professionals. In addition, we identified an extremely small number of solely nonverbal responses. The response could be nonverbal without any contact, but also could be a gesture, eye contact or a touch. The professionals expressed themselves with a varied range of nonverbal acts (e.g. touching, gestures and facial expressions) in line with the verbal input. Like the analysed initiatives, those in line with verbal responses were interpreted as verbal. In 5 of the 12 analysed play sessions, signs were 
Table 3 ECSE professionals' responses

\begin{tabular}{|c|c|c|c|c|c|}
\hline Main category & $\mathrm{n}$ & Percent & Subcategory & Meaning & Example (play) \\
\hline Unnoticed & 27 & 9 & Unnoticed initiative & $\begin{array}{l}\text { Doesn't notice (nonverbal or verbal } \\
\text { initiative) goes on playing with } \\
\text { other child/children }\end{array}$ & $\begin{array}{l}\text { A boy comes nearby, claps his } \\
\text { hands-the teacher keeping eye } \\
\text { contact to another boy, doesn't } \\
\text { notice (A1) }\end{array}$ \\
\hline Ignored & 16 & 5.4 & Ignored initiative & $\begin{array}{l}\text { Notices, doesn't answer, goes on } \\
\text { playing with other child/children }\end{array}$ & $\begin{array}{l}\text { A girl comes and taps her elbow (in a } \\
\text { play role)-the teacher takes a look, } \\
\text { keeps playing with others (A3) }\end{array}$ \\
\hline \multirow[t]{3}{*}{ Non-verbal } & 4 & 1.3 & Physical negative & $\begin{array}{l}\text { (Negative)gesture, touching without } \\
\text { any eye-contact, a response to a } \\
\text { negatively interpreted initiative }\end{array}$ & $\begin{array}{l}\text { A boy takes a seat next another boy- } \\
\text { the teacher moves her chairs chair } \\
\text { between the children }(\mathrm{C} 2)\end{array}$ \\
\hline & 4 & 1.3 & Physical approval & $\begin{array}{l}\text { Eye-contact, nodding, (positive) } \\
\text { gesture, coming nearby, hugging }\end{array}$ & $\begin{array}{l}\text { A boy directs a verbal initiative to his } \\
\text { peer-the teacher looks at his eyes, } \\
\text { nods and smiles (B2) }\end{array}$ \\
\hline & 4 & 1.3 & Contradicting nonverbal/verbal & $\begin{array}{l}\text { Nonverbal and verbal expression in } \\
\text { contradiction }\end{array}$ & $\begin{array}{l}\text { 'Can I come?'- - the teacher says } \\
\text { 'Yes, you can', but turns back to } \\
\text { another child and continued with } \\
\text { him (A3) }\end{array}$ \\
\hline \multirow[t]{7}{*}{ Verbal } & 94 & 32 & Commenting, reinforcing & $\begin{array}{l}\text { Repeating, commenting (in a play } \\
\text { role) }\end{array}$ & $\begin{array}{l}\text { 'You have a tractor' (A2) 'We have a } \\
\text { case of emergency' (A3) }\end{array}$ \\
\hline & 60 & 20.3 & Verbalizing & $\begin{array}{l}\text { Verbalizing, interaction pays atten- } \\
\text { tion to the initiative }\end{array}$ & $\begin{array}{l}\text { 'The police drove here' (A1) 'Look, } \\
\text { wild animals behind the fence' (A2) }\end{array}$ \\
\hline & 17 & 6 & Interpreting & $\begin{array}{l}\text { Interpreting (nonverbal or verbal) } \\
\text { message }\end{array}$ & $\begin{array}{l}\text { A boy takes the teacher's hand and } \\
\text { points to the bed—-the teacher: } \\
\text { "Let's ask the girls if you may go } \\
\text { there" (B3) }\end{array}$ \\
\hline & 51 & 17.3 & Expanding & $\begin{array}{l}\text { Catching the initiative, expanding } \\
\text { (in a play role) }\end{array}$ & $\begin{array}{l}\text { 'A cake? What do you put on it' } \\
\text { (A2) 'Do you need a doctor here?' } \\
\text { (A3) }\end{array}$ \\
\hline & 14 & 4.8 & Verbal controlling & $\begin{array}{l}\text { Controlling response to negatively } \\
\text { interpreted initiative }\end{array}$ & 'Stop fussing!' (C2) \\
\hline & 4 & 1.3 & Verbal permissive & $\begin{array}{l}\text { Turning initiative forward to other } \\
\text { children, aiming towards interac- } \\
\text { tion }\end{array}$ & $\begin{array}{l}\text { 'Have you already registered your- } \\
\text { self?' (A3) } \\
\text { 'Do you need somebody to help } \\
\text { you?-Somebody must go and } \\
\text { help!' (B2) }\end{array}$ \\
\hline & $\mathrm{N}=295$ & 100 & & & \\
\hline
\end{tabular}

Table 4 The quantification of the initiative-responseconsequence-chains

\begin{tabular}{lllll}
\hline Initiative- & Response- & Consequence & $\mathrm{n}$ & Percent \\
\hline $\begin{array}{llll}\text { Nonverbal- } \\
\text { Verbal- }\end{array}$ & Unnoticed/Ignored- & No interaction & $(50)$ & \\
& Unnoticed/Negative- & No interaction & $(25)$ & \\
Nonverbal- & Verbal- & & 75 & 25 \\
Verbal- & Verbal- & Adult-child interaction & $(37)$ & \\
& & Adult-child interaction & $(33)$ & \\
Nonverbal- & Verbal- & & 70 & 24 \\
Verbal- & Verbal- & Peer interaction & $(41)$ & \\
& & Peer interaction & $(109)$ & \\
& & & 150 & 51 \\
& & $\mathrm{~N}=295$ & & 100 \\
\hline
\end{tabular}

used to augment the spoken language. When nonverbal and verbal expressions appeared in contradiction (see Table 4), the nonverbal was interpreted as dominating, and the response was defined as nonverbal. The verbal responses included commenting, verbalizing, interpreting or expanding the initiative by supporting and maintaining interaction during the play. 


\section{Chains of Initiatives, Responses and Consequences}

Three different kinds of consequences emerged from the data: no interaction at all, dyadic adult-child interaction, and peer interaction. The latter is comprised of short interactive moments as well as lengthy reciprocal interactions and (role) play. Two main combinations of initiatives and responses leading to these three consequences were verbal-verbal, especially when the initiative was directed to an adult, to other children or to play, and nonverbal (or nondirected)—unnoticed/ignored. These however, were considerably fewer in number (Table 4).

We also identified other kinds of chains: a small number of nonverbal initiatives was followed by verbal responses, while some of the verbal initiatives either remained unnoticed or had nonverbal responses. Various nuances occurred as well, for example (adult-) directed initiatives, either nonverbal or verbal, elicited mostly verbal responses, whereas non-directed initiatives remained often unanswered. Reaction to a functional-verbal initiative was a nonverbal or verbal response leading to all kinds of consequences. Moreover, we recognized differences among the ECSE professionals. Missing or ignoring the initiatives was emphasized by some of them; others used wider repertories of nonverbal and verbal responses, while still others engaged in verbal variety. In our previous study (see Syrjämäki et al. 2017), a wider range of positive responses as well as peer interactions in consequence were identified in groups representing higher quality.

\section{Examples of the Findings}

\section{The Unnoticed and Ignored Initiatives}

Among the patterns identified, some of the initiatives escaped the professionals' attention. We also found that, along with nonverbal initiatives, non-directed verbal initiatives frequently went unnoticed. In the following example, ${ }^{2}$ the teacher is playing "doctor" with a small group of children, including Anne, a girl with limited verbal communication abilities, and her typically developing peers Tom, Linda and Sofia.

\section{Example 1 (Play A2)}

Anne has been to see the doctor earlier, and the teacher as the doctor has treated her elbow and sent her "home." She is sitting on a sofa, holding her elbow. The teacher is taking care of another patient, Linda with Tom, who plays the nurse. After a while, the teacher asks Anne to go the receptionist, Sofia, to register and come back to show her broken elbow

\footnotetext{
${ }^{2}$ About the examples, see Online Appendix 1.
}

again. Anne walks over to Sofia. She tells her name, but doesn't answer when Sofia asks what happened to her elbow. "You may go in now," says Sofia, pointing to the doctor. Anne doesn't answer but moves towards the doctor.

The teacher and Tom seem to be ready with Linda, who doesn't want to leave: "But I'm dying."

"Guess what, yesterday a dinosaur bit me. I shall die soon." The teacher keeps treating Linda together with Tom. Anne moves closer, pointing at her elbow, then waiting. Sofia leaves her place as a receptionist, passes Anne, and approaches the doctor: "Now I am a patient." "We have a case of extreme emergency here," answers the teacher. "But I'm ill!" argues Sofia. Anne stands by, holding her elbow and tapping it from time to time. The teacher keeps on treating Linda. "My knee hurts," says Sofia. "What a busy day," says the teacher, then to Sofia: "Come on, then, we'll examine you. Then, to Anne, "Have you registered yet? We take the urgent cases first."

The example revealed two of the identified initiative-response-consequence chains. First, the nonverbal initiatives taken by Anne (holding or tapping her elbow as a non-directed gesture and moving towards the others who are playing) were overlooked by the teacher, and no interaction arose between Anne and the others. The teacher's last line also showed that the interplay between Anne and Sofia at the beginning of the excerpt escaped her attention. Second, the verbal initiatives taken by Sofia (in line with the nonverbal initiatives) elicited verbal responses (as well as nonverbal, again in line with the verbal responses) and led to interactive play, while Anne's initiatives were ignored, and she was left in a passive role. In the successive sequences during unnoticed nonverbal initiatives, it appeared that if the initiating child was persistent and repeated the initiative again and again, the adult might notice, and before long the response could lead to interaction. Still, in many cases the child did not repeat his/her initiative, the response remained unsettled and the interaction was not fulfilled.

\section{Interpreting the Initiative and Enhancing Peer Interaction}

We found that when a child does not have much interactive play or communicative speech, his/her participation in a peer group can consist of showing interest in participation, following the playing peers or following parallel play activities. In the next example, the teacher is interpreting the child's nonverbal initiative and, by inviting other children to join the play, empowers the child's nonverbal and parallel participation. In the excerpt six children are playing together in the room. Among them, Jon and Aleksi are boys with SEN, and Elisa is a typically developing girl. 


\section{Example 2 (Play B.3)}

Aleksi has been driving an underground train made of small bricks near others who are playing. Then he leaves the train and goes to the other side of the room. Jon sees the train, takes it, and drives just like Aleksi was doing. After a while, Aleksi notices the train in Jon's hand. He finds a couple of bricks, joins them together and builds a short train and comes toward Jon, observing the play. He starts driving beside Jon. After a few minutes, Aleksi goes to the teacher and takes her hand. He turns toward Jon and flutters his hands. The teacher says, "Jon! Jon, guess what? Aleksi would like to have his train back." Aleksi flutters his hands again. Jon gives the longer train to Aleksi. "You could drive the train together; it's a really long train," proposes the teacher. "Maybe we could build a tunnel, shall we?" She takes some cloth from a large basket. Elisa comes along, "Yes, we may." Aleksi and Jon drive the train together, lying on the floor side by side. The teacher and Elisa build the tunnel on a bench with the large cloth. Then Elisa points out the tunnel and raises the edge of the cloth. Jon drives the train into the tunnel. "Look, Aleksi, where the train is going! Drive the [other] train there, too," suggests the teacher. The boys creep into the tunnel. Elisa keeps on building and spreads the cloth over the boys.

\section{Positive and Negative Chains}

Negative or negatively interpreted initiatives and two ways of responding to these were identified followed by two different consequences. In the first case (e.g. in play sessions $\mathrm{C} 1$ and $\mathrm{C} 2$ ), the initiatives that were nonverbal or verbal were interpreted as disturbing by the adult or by the other children. A child might have come close, seized or just reached out his hand for a toy, and the adult's response was verbal controlling: negatively tuned, restricting and leading away from interaction. Another kind of response in our data was identified as verbal permissive. In the following example, the initiative can be seen as aggressive: Aapo, a typically developing boy who is playing with plastic dinosaurs, is attacking a castle defended by the knight figures manoeuvred by another boy, Eero. Simo (a boy with SEN) is fighting back with an even bigger dinosaur. The teacher has been observing the play. She allows the rowdy game, even acts herself in role-play, but takes the opportunity to engage the boys' attention in more constructive interplay. The boys start to rebuild the castle and the play goes on.

\section{Example 3 (Play D.3)}

"Be careful, Big Dino," says the teacher. "You mustn't break the whole castle." "I'm breaking those dinosaurs," says Simo, playing with the big one. "Are you driving them away?" asks the teacher. Simo yells out with the sound of the dinosaur. Eero brings the knights close to the castle. The dinosaurs, played by Aapo and Simo, are fighting, the castle collapses and knights fall down. "Help, help, the castle is falling!" shouts the teacher. "My dinosaur is scared! AAARGH!" shouts Simo and beats on the other dinosaurs. The teacher restrains him by lightly touching Simo's hand. "Look, the dinosaurs are going away," she says, taking the dinosaurs further. "Look, they are here, faraway... But look, what happened to our castle - we have quite a job to build it back again. Let's start!" suggests the teacher" "Okay", Aapo agrees and starts to build. "Come along, Big Dino, help us. You are so strong!" praises the teacher.

\section{Two Different Patterns}

During play session A1 (see Online Appendix 1), the teacher and two boys with SEN were driving toy cars. The teacher maintained dyadic interaction with one boy at a time. She missed some initiatives and responded to others, but never guided the boys towards each other. Instead, a few times she even restrained the interaction by responding with a kind of negative or controlling physical movement. Still, during session A3 with one of these two boys and a typically developing girl, the same teacher responded to nonverbal and verbal initiatives taken by both children with verbal responses aimed at peer interaction. The difference between the two sessions was that, in the first, both boys had challenges with interaction, but in the second, the playmate was a typically developing girl who took many verbal initiatives.

\section{The Main Findings}

\section{Initiatives and Responses}

Our analyses revealed various ways of responding to the children's initiatives. However, verbal output dominated all the professionals' expressions. In regard to promoting peer interaction among the children, most of the responses of the ECSE professionals encouraged the child towards engaging with his peers and the play. The responses and the guidance were aimed not only at the children with additional needs, but also at any child with diverse characteristics. Nevertheless, some initiatives, especially nonverbal ones taken by children with SEN, remained unnoticed and the opportunities to enhance interaction were lost. Within the analysed play sessions including only children with SEN, the professional's responses were focused on the adult-child interaction instead of the interactions between the children. Moreover, when the adult was focused on observing, playing with or even controlling another child or children, the 


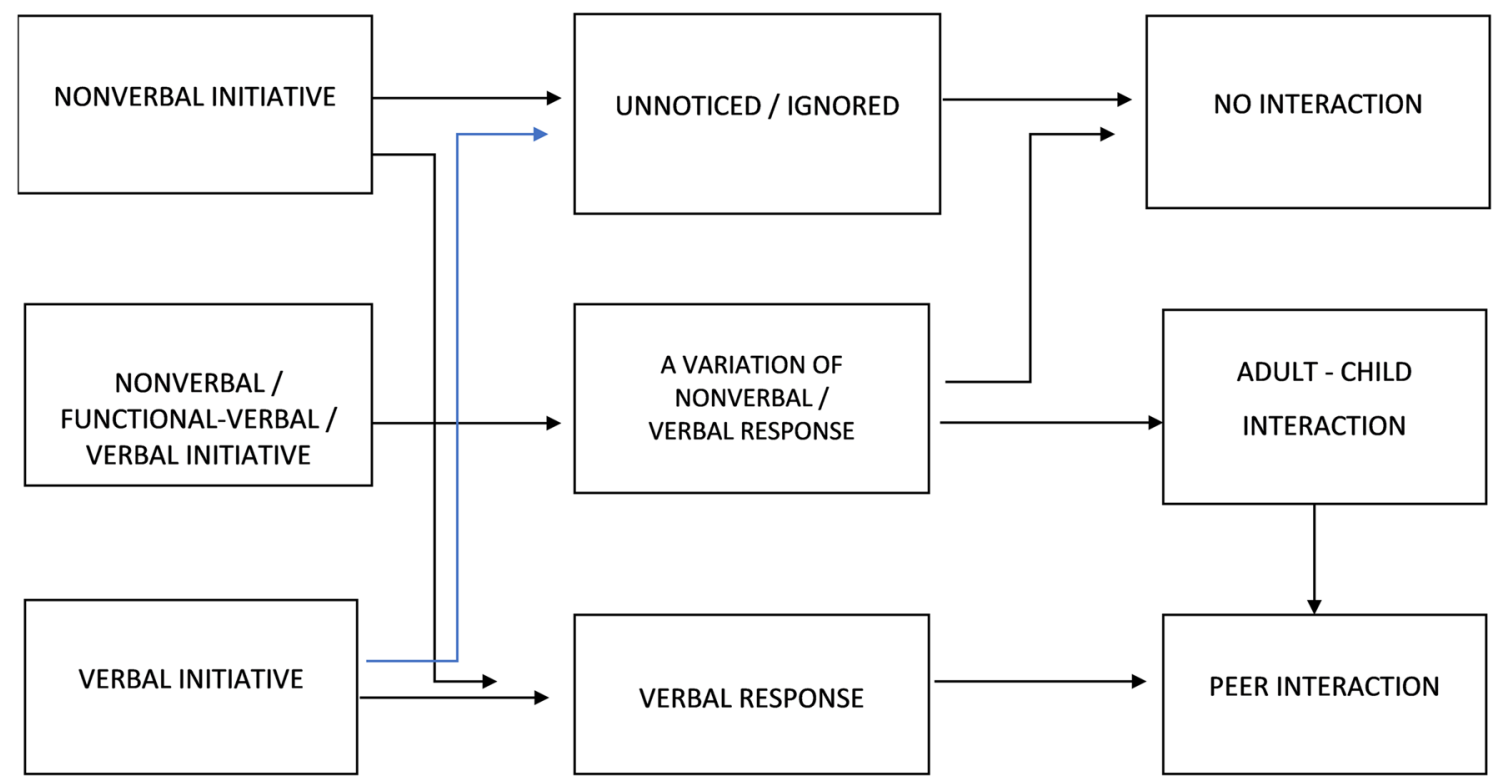

Fig. 1 The identified initiative-response-consequence chains

nonverbal initiatives were often unnoticed or ignored. A tendency to prefer verbal to nonverbal initiatives was identified in our study.

\section{Initiative-Response-Consequence Chains}

The primary model of the initiative-response-consequence chains consisted of nonverbal, functional-verbal or verbal initiatives, responded to by not noticing or ignoring the initiative or with a nonverbal or verbal response, while the consequences were no interaction, adult-child interaction or peer interaction. The response might be concentrated on dyadic interaction between an adult and a child but could also be directed to increasing interplay among the children. In a longer segment of the video data, it appeared that a warm dyadic interaction between an adult and a child could lead to peer interaction. The responses aimed at a group of children instead of a single child were succeeded by shorter or longer periods of peer interaction or interaction via participation (Fig. 1).

\section{Discussion}

This article focused on social initiatives made by children during guided play activities and the responses of professionals to these initiatives. We were interested in the kinds of consequences that followed from the chains of initiatives and responses. Our study revealed the diverse chains of nonverbal and verbal initiatives and the various pedagogical ways of responding to them, which in turn led to participation and interactive play, to dyadic adult-child interaction or to no interaction at all. Considering the initiatives taken here by children with SEN, only a few initiatives were misunderstood, unlike observations made in previous studies (see Paparella and Kasari 2004; Meyer and Ostrosky 2016). Our findings revealed that when an adult was focusing on observing or playing with one child - an important and desirable practice in itself - she missed some initiatives taken by the other children or even ignored some of the other children's initiatives. In these play situations the adult was concentrating only on playing, conducting uni-dimensional guidance, a concept we defined in our previous study (see Syrjämäki et al. 2018). Furthermore, in a few cases we also identified a tendency to favour verbal over nonverbal initiatives. In studying the responsive strategies of early childhood professionals, Girolametto and Weitzman (2002) suggested that group-directed, interaction-promoting strategies were related to children's advanced language skills, and that the caregivers' versatile response strategies were matched by interactive children. Based on our findings, we believe that the uni-dimensional interaction could inhibit the recognition of other children's initiatives. Early childhood professionals need to be sensitive enough to recognize nonverbal initiatives in particular; otherwise, they may tend to interact with those children who have advanced communication abilities at the expense of their less communicative peers.

It was interesting to observe that the same teacher with the same child used different response strategies in different play sessions. Further, the strategies had different consequences: adult-child interaction or peer interaction. We hypothesize that when diverse children were involved 
in play, the pedagogical goal was to improve the social and interaction skills. When only children with SEN and limited communicative abilities were involved in the play, the goal was more or less to provide individual educational support. In this connection Barton (2015) has suggested that teaching how to play may be a part of the trajectory towards any play-related learning goals for an individual child. However, that highlights the significance of play as a tool for assessing development or as an area of intervention (Kilburn and Mills 2014) and places the focus on the characteristics of a child instead of on shared activity and togetherness, conceptualized as interpersonal engagement in participation (Janson 2001; Rogoff 2008). From this point of view, the crucial question is: "For what reason and on what grounds are play pairs or groups created?" To scaffold the play, van Kuyk (2011) called for a rich, emotionally safe, and well-structured physical and psychological environment in which the actual scaffolding would appear on three planes: the teacher's presence, co-operation and enriching play. Moreover, social scaffolding includes the teacher's adjusting the environment and facilitating positive interaction in the zone of proximal development (Acar et al. 2017; Luttropp and Granlund 2010). Based on our findings, we suggest that the way the play group is formed and the role taken by the professionals in that process are important aspects of scaffolding the play and encouraging interaction in a group of children.

Our previous study highlighted the pedagogy of peer interaction instead of focusing on the individual child and the dyadic adult-child relation (Syrjämäki et al. 2018; see Hillerøy 2016). In addition to those findings, the present results revealed that a dyadic interaction can be realized as a step to interactive play. A substantial number of studies have highlighted the importance of the warm adult-child relationship or the teacher's instructional and emotional support in early years for motivation, learning and avoiding exclusion, especially for those children who are at developmental risk (e.g. Repo 2015; Rasku-Puttonen et al. 2012; Pakarinen et al. 2010; Hamre and Pianta 2005). To judge from our findings, the ECSE professionals' pedagogical sensitivity plays the key role. This sensitivity appears in identifying children's initiatives and responding to them, both at the group and at the individual levels, and in scaffolding children to interact with each other (see Acar et al. 2017; Singer et al. 2014; Bae 2012; Suhonen 2009; de Groot Kim 2005). Obviously, human beings' perceptual abilities to observe wide ranges of activities simultaneously are limited. It is difficult to attend to everything; in particular, responding to one child's initiatives while interacting with other children is challenging. Nevertheless, our findings call for professionals to develop attentive flexibility between engaged play with children and observing, supporting and responding to the initiatives with a variety of nonverbal and verbal responses.

\section{Concluding Thoughts and Implications}

In studying the pedagogy of enhancing peer interaction, notwithstanding the fact that all kinds of children participated in our study, our focus emphasized slightly the vantage point of the children with special needs. Still, we state that committed support in joining and interacting in play benefits a diversity of children, both those who are developing typically and those with SEN. That support requires sensitivity in spontaneously recognizing those who need scaffolding and what kind of scaffolding is necessary during group activities. That highlights the relevance of our conclusions both in inclusive education as well as in early childhood special education.

We close by pointing out two implications. One is for professional reflection: $\mathrm{EC}(\mathrm{S}) \mathrm{E}$ professionals should review their own sensitivity to nonverbal initiatives, while recognizing their importance; for example, becoming aware of what kinds of (pedagogical) activities or guidance enable them to identify nonverbal initiatives. Consciousness of the initiatives or interactions of children with special needs is especially crucial. We also suggest increasing the awareness and reflections on the use of nonverbal expressions, particularly those without simultaneous verbal input, the appearance of which remained quite low in our study. Second, we recommend some areas for further investigation. In-depth studies are needed that focus on the quality and content of the interactions and relationships among diverse children, including those with special needs of various kinds. Different professional backgrounds in relation to the implemented pedagogy frames another interesting perspective, which would sustain and sharpen the research on pedagogy aimed at increasing peer interaction and participation in early childhood educational contexts.

Acknowledgements Open access funding provided by University of Helsinki including Helsinki University Central Hospital.

Funding This study was Granted by the Research Fund of the Mannerheim League for Child Welfare.

\section{Compliance with Ethical Standards}

Conflict of interest The authors declare that they have no conflict of interest.

Ethical Approval All procedures performed in studies involving human participants were in accordance with the ethical standards of the institutional and/or national research committee and with the 1964 Helsinki Declaration and its later amendments or comparable ethical standards. The study has been accepted by the Municipal Department of Early Education and Care. The adult participants and the parents of the participating children gave written consent to be part of the study, expressed in response to a letter containing information about the goals and the procedures of the research as well as about the use of and access to the research material. The procedure was also discussed with 
the participating children before the video recordings. All participants were given the opportunity to withdraw from the study at any stage.

Open Access This article is distributed under the terms of the Creative Commons Attribution 4.0 International License (http://creativeco mmons.org/licenses/by/4.0/), which permits unrestricted use, distribution, and reproduction in any medium, provided you give appropriate credit to the original author(s) and the source, provide a link to the Creative Commons license, and indicate if changes were made.

\section{References}

Acar, I. H., Hong, S.-Y., \& Wu, C. (2017). Examining the role of teacher presence and scaffolding in preschoolers' peer interactions. European Early Childhood Education Research Journal, 25(6), 866-884.

Anderson, D. H., Trinh, S. M., Caldarella, P., Hansen, B. D., \& Richardson, M. J. (2017). Increasing positive playground interaction for kindergarten students at risk for emotional and behavioral disorders. Early Childhood Education Journal, 46, 487-496.

Bae, B. (2012). Children and teachers as partners in communication: Focus on spacious and narrow interactional patterns. International Journal of Early Childhood, 44(1), 53-69.

Barton, E. E. (2015). Teaching generalized pretend play and related behaviors to young children with disabilities. Exceptional Children, 8(4), 489-506.

Bodrova, E., \& Leong, D. J. (2007). Tools of the mind (2nd ed.). Englewood Cliff: Merrill/Prentice Hall.

Brodin, J. (2005). Diversity of aspects on play in children with profound multiple disabilities. Early Child Development and Care, 175(7-8), 635-646.

Brown, W. H., Odom, S. L., \& Conroy, M. A. (2001). An intervention hierarchy for promoting young children's peer interaction in natural environments. Topics in Early Childhood Special Education, $21(3), 162-175$

Burgeon, J. K., Guerrero, L. K., \& White, C. H. (2013). The codes and functions of nonverbal communication. In A. J. Cienki, E. Fricke, S. H. Ladewick, D. McNeil, C. Müller, \& S. Tessendorf (Eds.), Body - language - communication. An international handbook on multimodality in human interaction (Vol. 1, pp. 609-626). Berlin: De Gruyter Mouton.

Corsaro, W. A. (2005). The sociology of childhood (2nd ed.). Thousand Oaks: SAGE Publications.

de Groot Kim, S. (2005). Kevin: "I gotta get to the market": The development of peer relationships in inclusive early childhood settings. Early Childhood Education Journal, 33(3), 163-169.

Derry, S. J., Pea, R. D., Barron, B., Engle, R. A., Erickson, F., Goldman, R., et al. (2010). Conducting video research in the learning sciences: Guidance on selection, analysis, technology, and ethics. The Journal of the Learning Sciences, 19, 3-53.

Flewitt, R. (2006). Using video to investigate preschool classroom interaction: Education research assumptions and methodological practices. Visual Communication, 5(1), 25-50.

Flick, U. (2007). Managing quality in qualitative research: A focus on process and transparency. In U. Flick (Ed.), Managing quality in qualitative research. London: Sage.

Fusch, P. I., \& Ness, L. R. (2015). Are we there yet? Data saturation in qualitative research. The Qualitative Report, 20(9), 1408-1416.

Girolametto, L., \& Weitzman, E. (2002). Responsiveness of child care providers in interactions with toddlers and preschoolers. Language, Speech and Hearing Services in Schools, 33, 268-281.
Hamre, B. K., \& Pianta, R. C. (2005). Can instructional and emotional support in the first-grade classroom make a difference for children at risk of school failure? Child Development, 6(5), 949-967.

Hillerøy, S. (2016). The contribution of support teachers in facilitating children's peer interaction. International Journal of Early Childhood, 48(1), 95-109.

Janson, U. (2001). Togetherness and diversity in pre-school play. International Journal of Early Years Education, 9(2), 135-143.

Juutinen, J. (2015). Lasten yhteenkuuluvuuden rakentuminen päiväkotiarjen pienissä kertomuksissa. [The construction of children's belonging through the small daily stories in day care centres]. Journal of Early Childhood Education Research, 4(2), 159-179.

Kemp, C., Kishida, Y., Carter, M., \& Sweller, N. (2013). The effect of activity type on the engagement and interaction of young children with disabilities in inclusive childcare settings. Early Childhood Research Quarterly, 28(1), 134-143.

Kilburn, V., \& Mills, K. (2014). Play for children with special educational needs. In A. Brock, P. Jarvis, \& Y. Olusoga (Eds.), Perspectives on. Play learning for life (2nd ed., pp. 211-231). New York: Routledge.

Koster, M., Nakken, H., Pijl, S. J., \& van Houten, E. (2009). Being part of the peer group: A literature study focusing on the social dimension of inclusion in education. International Journal of Inclusive Education, 13(2), 117-140.

Kronqvist, E. (2004). Mitä lapsiryhmässä tapahtuu? Pienten lasten yhteistoiminta, sen rakentuminen ja kehittyminen spontaaneissa leikkitilanteissa. [What happens in a group of children? Collaboration of small children, its construction and development in spontaneous play situations]. Doctoral thesis, University of Oulu, Finland.

Kultti, A. (2015). Adding learning resources: A study of two toddlers' modes and trajectories of participation in early childhood education. International Journal of Early Years Education, 22(2), 209-221.

Laaksonen, V. (2014). Lasten vertaissuhdetaidot ja kiusaaminen esikoulun vertaisryhmässä. [Children's peer interaction skills and bullying in the peer groups of preschool]. Doctoral thesis, University of Jyväskylä, Finland.

Luttropp, A., \& Granlund, M. (2010). Interaction-it depends-A comparative study of interaction in preschools between children with intellectual disability and child with typical development. Scandinavian Journal of Disability Research, 12(3), 151-164.

Meyer, L. E., \& Ostrosky, M. M. (2016). Impact of affective intervention on the friendships of kindergartners with disabilities. Topics in Early Childhood Special Education, 35(4), 200-210.

Movahedazarhouligh, S. (2018). Teaching play skills to children with disabilities: Research-based interventions and practices. Early Childhood Education Journal, 46, 587-599.

Pakarinen, E., Kiuru, N., Lerkkanen, M.-L., Poikkeus, A.-M., Siekkinen, M., \& Nurmi, J.-E. (2010). Classroom organization and teacher stress predict learning motivation in kindergarten children. European Journal of Psychology of Education, 25(3), 281-300.

Paparella, T., \& Kasari, C. (2004). Joint attention skills and language development in special needs populations: Translating research to practice. Infants \& Young Children, 17(3), 269-280.

Pihlaja, P. (2009). Erityisen tuen käytännöt varhaiskasvatuksessa näkökulmana inkluusio. [The special education practices in early childhood education - inclusion as a viewpoint]. Kasvatus, 2 , 146-156.

Pink, S. (2007). Doing visual ethnography: Images, media and representation in research ( 2 nd ed.). Thousand Oaks: SAGE Publications.

Rasku-Puttonen, H., Lerkkanen, M. K., Poikkeus, A. M., \& Siekkinen, M. (2012). Dialogical patterns of interaction in pre-school classrooms. International Journal of Educational Research, 53, $138-149$. 
Repo, L. (2015). Bullying and its prevention in early childhood education. Doctoral thesis, University of Helsinki, Finland.

Rogoff, B. (2008). Observing sociocultural activity in three planes: Participatory appropriation, guided participation, and apprenticeship. In K. Hall, P. Murphy, \& J. Soler (Eds.), Pedagogy and practice: Culture and identities (pp. 58-74). Milton Keynes: Open University.

Ryan, R. M., \& Deci, E. L. (2000). Self-determination theory and the facilitation on intrinsic motivation, social development, and wellbeing. American Psychologist, 55(1), 68-78.

Schaffer, R. (2006). Key concepts in developmental psychology. London: SAGE Publications.

Schreier, M. (2012). Qualitative content analysis in practice. London: SAGE Publications.

Seale, C. (1999). Reliability and replicability. In C. Seale (Ed.), The quality of qualitative research. London: Sage.

Singer, E., \& de Haan, D. (2007). Social life of young children. Coconstruction of shared meanings and togetherness, humor, and conflicts in child care centers. In O. N. Saracho \& B. Spodek (Eds.), Contemporary perspectives on social learning in early childhood education (pp. 279-302). Charlotte, NC: Information Age Pub.

Singer, E., Nederent, M., Penninx, L., Tajik, M., \& Boom, J. (2014). The teacher's role in supporting young children's level of play engagement. Early Child Development and Care, 184(8), 1233-1249.

Smith, E., Næss, K.-A., \& Jarrold, C. (2017). Assessing pragmatic communication in children with Down syndrome. Journal of Communication Disorders, 68, 10-23.

Strain, P. S., \& Joseph, G. E. (2004). Engaged supervision to support recommended practices for young children with challenging behavior. Topics in Early Childhood Special Education, 24(1), 39-50.

Suhonen, E. (2009). Erityistä tukea tarvitsevan taaperon sopeutuminen päiväkotiryhmään. Monitapaustutkimus vuorovaikutussuhteista ja niiden rakentumisesta lapsiryhmässä. [How toddlers with special needs adjust to the day care setting. A multiple case study of how the relationships with adults and children are built] Doctoral thesis, University of Helsinki, Finland.

Suhonen, E., Nislin, M., Alijoki, A., \& Sajaniemi, N. K. (2015). Children's play behaviour and social communication in integrated special day-care groups. European Journal of Special Needs Education, 30(3), 287-303.

Syrjämäki, M., Pihlaja, P., \& Sajaniemi, N. (2018). Enhancing peer interaction during guided play in Finnish integrated special groups. European Early Childhood Education Research Journal, 26(3), 418-431.

Syrjämäki, M., Sajaniemi, N., Suhonen, E., Alijoki, A., \& Nislin, M. (2017). Enhancing peer interaction: An aspect of a high-quality learning environment in Finnish early childhood special education. European Journal of Special Needs Education, 32(3), 377-390.

Terpstra, J. E., \& Tamura, R. (2008). Effective social interaction strategies for inclusive settings. Early Childhood Education Journal, 35(5), 405-411.

van Kuyk, J. J. (2011). Scaffolding-How to increase development? European Early Childhood Education Research Journal, 19(1), 133-146.

Viljamaa, E., Estola, E., Juutinen, J., \& Puroila, A.-M. (2017). Patjakasan kutsu - yhteen tulemisia ja erilleen vetäytymisiä päiväkodissa. [Around a heap of mattresses-Becoming together and apart in a day care centre] Journal of Early Childhood Education Research, 6(1), 2-21.

Publisher's Note Springer Nature remains neutral with regard to jurisdictional claims in published maps and institutional affiliations. 